\title{
Yield of lettuce grown in hydroponic and aquaponic systems using different substrates
}

\author{
Rodrigo A. Jordan ${ }^{1}$, Evaldo F. Ribeiro ${ }^{1}$, Fabricio C. de Oliveira ${ }^{1}$, \\ Luciano O. Geisenhoff ${ }^{1} \&$ Elton A. S. Martins ${ }^{1}$ \\ ${ }^{1}$ Universidade Federal da Grande Dourados/Faculdade de Ciências Agrárias. Dourados, MS. E-mail: rodrigojordan@ufgd.edu.br - ORCID: 0000-0002- \\ 2479-4461; evaldo.fernandes.ribeiro@gmail.com - ORCID: 0000-0003-4571-9986; fabriciooliveira@ufgd.edu.br (Corresponding author) - ORCID: \\ 0000-0002-7373-0667; lucianogeisenhoff@ufgd.edu.br - ORCID: 0000-0002-5907-5870; eltonmartins@ufgd.edu.br - ORCID: 0000-0002-3195-2317
}

\section{Key words:}

Lactuca sativa soilless cultivation coconut shell fiber tilapia

\begin{abstract}
A B S T R A C T
This study had as objective to evaluate the effect of the substrate on the yield of lettuce grown in aquaponic and hydroponic systems. The study was conducted at the Federal University of Grande Dourados, located in Dourados, MS. A randomized complete block design was used, with three treatments and 16 replicates. The cultivation systems were analyzed independently. The substrates analyzed were: coconut shell fiber, phenolic foam and expanded vermiculite. The plants were grown in two systems (aquaponic and hydroponic), using the NFT (Nutrient Film Technique) system. The crop used was lettuce cv. 'Alcione'. The parameters analyzed were: crop yield and percentage of roots per plant. In addition, macronutrient contents were analyzed in the leaves. The substrate composed of coconut shell fiber was more suitable for lettuce production, since it led to higher yields for both aquaponic $\left(2.88 \mathrm{~kg} \mathrm{~m}^{-2}\right)$ and hydroponic $\left(2.58 \mathrm{~kg} \mathrm{~m}^{-2}\right)$ systems. The use of phenolic foam as growing substrate led to lower mean crop yields in both production systems analyzed, 1.94 and $2.15 \mathrm{~kg} \mathrm{~m}^{-2}$ for aquaponic and hydroponic systems, respectively.
\end{abstract}

\section{Palavras-chave:}

Lactuca sativa

cultivo sem solo

fibra de casca de coco

tilápia

\section{Produtividade da alface cultivada em sistema de hidroponia e aquaponia utilizando diferentes substratos}

\section{R E S U M O}

Nesta pesquisa objetivou-se avaliar o efeito do substrato sobre a produtividade da alface cultivada em sistema aquapônico e hidropônico. A pesquisa foi realizada na Universidade Federal da Grande Dourados, localizada em Dourados, MS. Foi utilizado o delineamento em blocos ao acaso, com três tratamentos e 16 repetições. Os sistemas de cultivo foram analisados de forma independente. Os substratos analisados foram: fibra de casca de coco, espuma fenólica e vermiculita expandida. As plantas foram cultivas em dois sistemas (aquapônico e hidropônico), sendo utilizado o sistema do tipo NFT (Nutrient Film Technique). A cultura utilizada foi a alface cv. Alcione. Os parâmetros analisados foram: produtividade da cultura e porcentagem de raiz por planta. Além disso, foram realizadas análises de macronutrientes presentes nas folhas das plantas. $\mathrm{O}$ substrato constituído de fibra de casca de coco foi mais adequado para o cultivo de alface, uma vez que proporcionou maiores produtividades, tanto para o sistema aquapônico $\left(2,88 \mathrm{~kg} \mathrm{~m}^{-2}\right)$, quanto para o sistema hidropônico $\left(2,58 \mathrm{~kg} \mathrm{~m}^{-2}\right)$. A utilização de espuma fenólica, como substrato de cultivo, proporcionou menor média para produtividade da cultura, em ambos os sistemas de produção analisados, com valores para o cultivo aquapônico e hidropônico de 1,94 e $2,15 \mathrm{~kg} \mathrm{~m}^{-2}$, respectivamente. 


\section{INTRODUCTION}

The term aquaponics refers to a set of technologies that integrate fish farming and plant cultivation in a symbiotic system (Goddek et al., 2016). While fish farming wastes are used as fertilizers for the production of plants, their cultivation contributes to removing metabolic substances which can be harmful to fish development, acting on the quality of the water used for fish farming (Roosta \& Afsharipoor, 2012; Hundley et al., 2013).

Regarding the substrates used in soilless cultivation systems (hydroponics and aquaponics), they provide support to the plants and act as a small reservoir of nutrients. Thus, the utilization of inadequate substrates may lead to reduction in the productive parameters of the crops, as observed for lettuce and tomato (Salam et al., 2014; Geisenhoff et al., 2016). In the cultivation in aquaponic system, substrates must have a fixing surface for microorganisms, responsible for converting nutrients to forms readily available to plants (Jordan et al., 2018).

In some countries such as United States, Australia and also in the European continent, the aquaponic technique is widely employed on the most different scales, from research units and small properties to large commercial units (Love et al., 2015). In Brazil, the commercial units are virtually inexistent. However, studies have been carried out aiming to adapt the system to the national conditions (Hundley et al., 2013; Geisenhoff et al., 2016; Jordan et al., 2018).

Thus, it becomes necessary to carry out studies aiming to generate information on the forms of conduction of aquaponic systems, allowing for implementation on commercial scale under Brazilian conditions. This study aimed to evaluate the effect of substrate on the yield of lettuce grown in aquaponic and hydroponic systems.

\section{Material AND Methods}

The study was carried out in a protected environment, in the aquaponics experimental area of the Faculty of Agrarian Sciences (FCA) of the Federal University of Grande Dourados (UFGD), located in Dourados, Mato Grosso do Sul, Brazil $\left(22^{\circ}\right.$ $11^{\prime} 45^{\prime \prime} \mathrm{S}, 54^{\circ} 55^{\prime} 18^{\prime \prime} \mathrm{W}$; $446 \mathrm{~m}$ of altitude).

The aquaponic system was composed of two rearing tanks, one pumping and heating tank, one decanter and one biological filter (Figure 1).

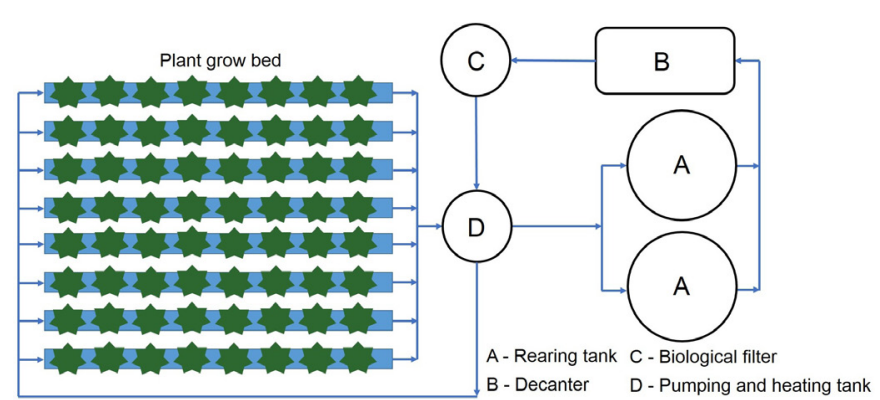

Figure 1. Scheme of the main components of the aquaponic system
Each rearing tank has a volume of 1000 L. Fish population density was 100 fish $\mathrm{m}^{-3}$ (Coêlho et al., 2014). Tilapia (Oreochromis niloticus) fish, GIFT strain, were introduced in the rearing tank during the juvenile stage, weighing $142 \mathrm{~g}$ on average, and were fed twice a day using $500 \mathrm{~g} \mathrm{~d}^{-1}$ of extruded feed, containing $45 \%$ protein.

Twice a day, through valves installed at the base of the rearing tanks, fish wastes decanted at the bottom were collected and taken to the decanter. The decanter accumulated wastes for one week and, after this period, it was cleaned and the decanted fraction was removed.

The decanted fraction was taken to 50-L biodigesters, to generate the biofertilizer. The average time for the decanted effluent to be biodigested was approximately 15 days. The liquid fraction (wastewater) was separated and stored for subsequent mixture with the biofertilizer. The nutrient solution used for plant cultivation was composed of a mixture of wastewater and biofertilizer at a volumetric proportion of 100:6, as performed in studies on aquaponics under Brazilian conditions (Geisenhoff et al., 2016; Jordan et al., 2018).

The solution was stored in a 500-L fiberglass tank and was then pumped to the hydroponic system. Irrigations were performed in 15-min cycles. Every seven days, the volume that remained in the tank was replaced by a new nutrient solution. After passing through the plant growing system, the solution was accumulated in the heating tank and progressively conducted to the fish rearing tanks.

In both cultivation systems analyzed (hydroponic and aquaponic), plants were grown in a 3 -m-long NFT (Nutrient Film Technique) system, supported by a metal structure, with $3 \%$ slope and spacing of $20 \mathrm{~cm}$ from one another. The spacing between plants in the same row was also $20 \mathrm{~cm}$, totaling 12 plants per hydroponic profile.

The experimental design was randomized blocks, with three treatments and 16 replicates. The substrates analyzed were: coconut shell fiber, phenolic foam and expanded vermiculite. Each cultivation system had 16 profiles, with three plots. Plots contained four plants in one row, and the experimental unit was represented by the two central plants, disregarding the ends. The plots, composed by the different substrates, were randomly distributed in each profile. The results were subjected to Tukey test $(\mathrm{p}<0.05)$ and analyzed using the program Sisvar ${ }^{\circledast}$ (Ferreira, 2011).

Plants in the hydroponic system were fertilized using a commercial kit (Hidrogood Fert ${ }^{\oplus}$ ), composed of nitrogen (10\%), phosphorus (9\%), potassium (28\%), magnesium $(3.3 \%)$, sulfur $(4.3 \%)$, boron $(0.06 \%)$, copper $(0.01 \%)$, molybdenum $(0.07 \%)$, manganese $(0.05 \%)$ and zinc $(0.02 \%)$. In addition, $25 \mathrm{~g}$ of Fe-EDDHA were added. For these nutritional concentrations, the following nutrients were used: potassium nitrate, monoammonium phosphate, magnesium sulfate, boric acid, copper sulfate, sodium molybdate and zinc sulfate.

Plants were grown in different substrates: coconut shell fiber, phenolic foam and expanded vermiculite. The coconut shell fiber had apparent dry density of $150 \mathrm{~kg} \mathrm{~m}^{-3}$. The phenolic foam had $2.0 \times 2.0 \times 2.0 \mathrm{~cm}$ cells and apparent density of 10 $12 \mathrm{~kg} \mathrm{~m}^{-3}$. The expanded vermiculite was thin, with apparent density of $155 \mathrm{~kg} \mathrm{~m}^{-3}$. The species used was curly lettuce (Lactuca sativa), cultivar 'Alcione'. 
Plants were grown from February 24 to April 4, 2016. The substrates were prepared prior to sowing. Coconut shell fiber and expanded vermiculite were placed in perforated plastic cups with volume of $80 \mathrm{~cm}^{-3}$. The phenolic foam, previously washed, had a volume of $8 \mathrm{~cm}^{-3}$.

At 10 days after sowing, plants were transferred to the cultivation profiles. Until 29 days after sowing (DAS), plants were irrigated with the same nutrient solution, composed of the commercial kit for fertilization, in both cultivation systems. From 30 DAS on, the supply of commercial synthetic fertilizers was suspended to plants grown in the aquaponic system and these plants began to be irrigated with solution from the fish rearing system. In the hydroponic system, the nutrient solution was replaced by a new one.

After harvest, shoot fresh matter, root fresh matter and total fresh matter were determined. Then, crop yield was calculated and the ratio between root fresh matter and total fresh matter was used to calculate the percentage of roots per plant. In addition, eight plants from each treatment were collected and subjected to foliar analysis of macronutrients (calcium-Ca, magnesium-Mg, nitrogen-N, phosphorus-P and potassium-K).

After $30 \mathrm{DAS}$, the temperature, $\mathrm{pH}$, electrical conductivity and dissolved oxygen were daily measured in the waters of the hydroponic and aquaponic systems (Figure 2). The

A.
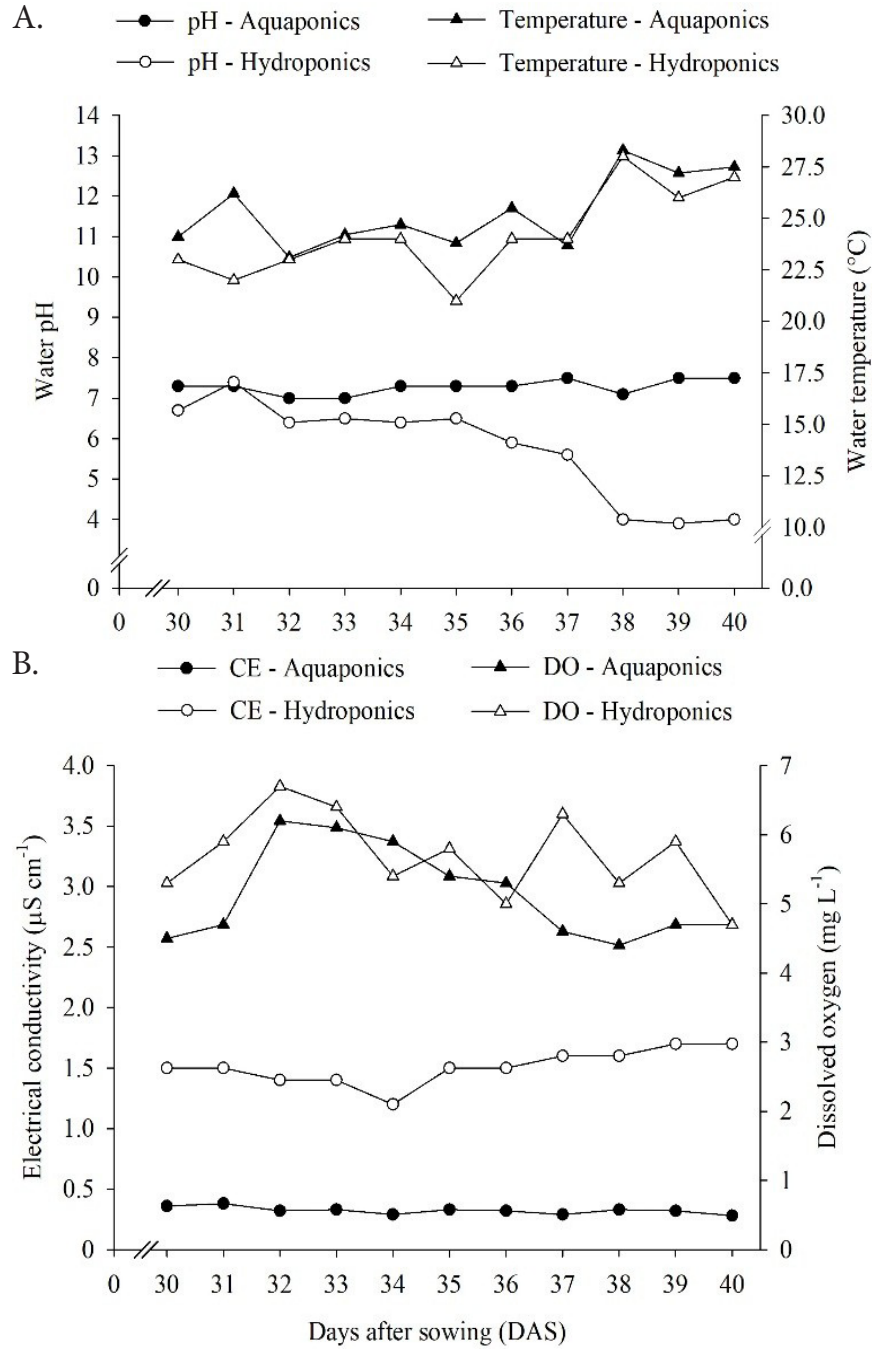

Figure 2. Water temperature and $\mathrm{pH}(\mathrm{A})$; electrical conductivity - EC and dissolved oxygen - DO (B) along the evaluation period measurements were taken in the nutrient solution before it entered the plant grow bed. The parameters were measured using a portable multiparameter meter (Instruterm-Orp ${ }^{\circ}$ ).

\section{Results AND Discussion}

For crop yield, the substrate composed of coconut shell fiber led to highest mean values, in both aquaponic $\left(2.88 \mathrm{~kg} \mathrm{~m}^{-2}\right)$ and hydroponic $\left(2.58 \mathrm{~kg} \mathrm{~m}^{-2}\right)$ systems. Phenolic foam led to the lowest mean yield in both systems analyzed (Table 1).

Regarding the yield in the aquaponic system, similar results were observed by Jordan et al. (2018). These authors compared the yield of lettuce cultivated in aquaponic system, using coconut shell fiber with crushed stone $\mathrm{n}^{\circ} 3$ and phenolic foam as substrates, and observed that, despite the higher values of yield, the coconut shell fiber with crushed stone $\mathrm{n}^{\circ} 3$ led to higher yield $\left(3.99 \mathrm{~kg} \mathrm{~m}^{-2}\right)$ in comparison to the phenolic foam $\left(2.08 \mathrm{~kg} \mathrm{~m}^{-2}\right)$. When analyzing the yield of a crop in an aquaponic system, one should not forget that plant production can be viewed as a tool to complement the profit obtained by fish farming, and it is a highly sustainable form of cultivation, because after the system is turned on only the volume equivalent to the evapotranspiration is replaced to the system (Roosta \& Afsharipoor, 2012).

Lower values of yield obtained using the phenolic foam can be attributed to the degradation process occurring along the cultivation of plants. Substrate degradation provides adverse conditions for the crop, since it reduces the retention time of the nutrients (Geisenhoff et al., 2016).

In general, yields obtained in hydroponic systems are higher when compared with the cultivation in soil and aquaponics. It occurs because, in the hydroponic system, nutrients are supplied in an readily available form to plants (Pôrto et al., 2012). Maximum yield of $5.11 \mathrm{~kg} \mathrm{~m}^{-2}$ for lettuce was observed in hydroponic cultivation (Martins et al., 2010); however, lettuce yields can be highly divergent. In conventional cultivation, with soil, the mean yields ranged from 0.58 to $3.6 \mathrm{~kg} \mathrm{~m}^{-2}$ during the crop cycles (Peixoto Filho et al., 2013).

To obtain high yields in soilless cultivation, variables that interfere with crop yield should be strictly controlled because small variations in water $\mathrm{pH}$, electrical conductivity and temperature can significantly compromise the production (Villela Júnior et al., 2004; Bezerra Neto \& Barreto, 2012). In the present study, it was observed that in the final period of cultivation there was a fast increase in water temperature, especially in the hydroponic cultivation, which changed from $23^{\circ} \mathrm{C}$ at $35 \mathrm{DAS}$ to $27.5^{\circ} \mathrm{C}$ at $40 \mathrm{DAS}$. In addition, water $\mathrm{pH}$ was close to 4 in the last three days of experiment.

An issue that can contribute to choosing the most adequate substrate for soilless cultivation is the development of the root system (Geisenhoff et al., 2016). In the comparison between

Table 1. Yield $\left(\mathrm{kg} \mathrm{m}^{-2}\right)$ of lettuce (Lactuca sativa cv. 'Alcione') in aquaponic and hydroponic systems as a function of different cultivation substrates

\begin{tabular}{lcc}
\hline \multicolumn{1}{c}{ Substrates } & \multicolumn{2}{c}{ Crop yield $\mathbf{~ ( k g ~ m}^{-2}$ ) } \\
\cline { 2 - 3 } Phenolic foam & Aquaponic system & Hydroponic system \\
Expanded vermiculite & $1.94 \mathrm{c}$ & $2.15 \mathrm{~b}$ \\
Coconut shell fiber & $2.42 \mathrm{~b}$ & $2.47 \mathrm{ab}$ \\
\hline
\end{tabular}

*Means followed by the same letters in the rows do not differ by Tukey test $(p<0.05)$ 
percentages of roots per plant, greater root development occurred in plants cultivated in coconut shell fiber, with values of 17.7 and $15.5 \%$ in aquaponic and hydroponic systems, respectively. Plants grown in phenolic foam showed lower root development for both aquaponic (13.8\%) and hydroponic (9.3\%) systems.

Regarding the contents of macronutrients in the leaves, it can be observed that plants suffered nutritional deficiency of $\mathrm{Ca}, \mathrm{Mg}, \mathrm{P}$ and $\mathrm{K}$ in both cultivation systems, considering the three substrates evaluated (Table 2).

Calcium contents were inadequate in the three substrates analyzed for both cultivation systems, because they were outside the recommended range from 15 to $25 \mathrm{~g} \mathrm{~kg}^{-1}$ (Raij et al., 1996). However, Almeida et al. (2011) reported similar results in hydroponic cultivation, with contents from 3.6 to $12.1 \mathrm{~g} \mathrm{~kg}^{-1}$.

With regard to $\mathrm{Mg}$, the three substrates in both cultivation systems led to values below the adequate range ( 4 to $6 \mathrm{~g} \mathrm{~kg}^{-1}$ ) according to Raij et al. (1996). In conventional cultivation, with soil, Kano et al. (2012) obtained results similar to those reported in the present study, with $\mathrm{Mg}$ contents between 3.1 and $3.6 \mathrm{~kg}^{-1}$.

According to Raij et al. (1996), leaf $\mathrm{N}$ contents were adequate for the three substrates evaluated, using the aquaponic system. For the hydroponic system, the N contents observed in the leaves were high in expanded vermiculite and coconut shell fiber, since they were outside the range from 30 to $50 \mathrm{~g} \mathrm{~kg}^{-1}$ of $\mathrm{N}$.

The $\mathrm{P}$ content in the shoots recommended by Raij et al. (1996) is between 4 and $7 \mathrm{~g} \mathrm{~kg}^{-1}$. Thus, the cultivation in aquaponic system led to adequate $\mathrm{P}$ contents. However, in the hydroponic system, the contents were below the adequate levels.

$\mathrm{K}$ contents in the leaf tissues were low for both cultivation systems, in the three substrates evaluated, since they were below the range from 50 to $80 \mathrm{~g} \mathrm{~kg}^{-1}$ of $\mathrm{K}$ (Raij et al., 1996). Similar results were found by Almeida et al. (2011), who observed $\mathrm{K}$ contents ranging from 3.2 to $58.9 \mathrm{~g} \mathrm{~kg}^{-1}$ in the hydroponic system.

Inadequate contents of $\mathrm{K}$, along with $\mathrm{Ca}, \mathrm{Mg}$ and $\mathrm{P}$, possibly contributed to the reductions of yield observed in the present

Table 2. Contents of nutrients $\left(\mathrm{g} \mathrm{kg}^{-1}\right)$ in the leaves of lettuce (Lactuca sativa cv. 'Alcione') grown in aquaponic and hydroponic systems as a function of different cultivation substrates

\begin{tabular}{|c|c|c|c|}
\hline \multirow[b]{2}{*}{ Nutrients } & \multirow[b]{2}{*}{ Substrates } & \multicolumn{2}{|c|}{ Leaf contents of nutrients $\left(\mathrm{g} \mathrm{kg}^{-1}\right)$} \\
\hline & & $\begin{array}{l}\text { Aquaponic } \\
\text { system }\end{array}$ & $\begin{array}{l}\text { Hydroponic } \\
\text { system }\end{array}$ \\
\hline \multirow{3}{*}{$\mathrm{Ca}$} & Phenolic foam & 9.90 & 8.27 \\
\hline & Expanded vermiculite & 8.78 & 5.98 \\
\hline & Coconut shell fiber & 8.40 & 4.81 \\
\hline \multirow{3}{*}{$\mathrm{Mg}$} & Phenolic foam & 3.45 & 3.97 \\
\hline & Expanded vermiculite & 3.11 & 3.42 \\
\hline & Coconut shell fiber & 3.64 & 3.67 \\
\hline \multirow{3}{*}{ N } & Phenolic foam & 46.20 & 50.58 \\
\hline & Expanded vermiculite & 46.55 & 54.08 \\
\hline & Coconut shell fiber & 44.80 & 55.83 \\
\hline \multirow{3}{*}{$P$} & Phenolic foam & 6.56 & 2.89 \\
\hline & Expanded vermiculite & 7.35 & 2.82 \\
\hline & Coconut shell fiber & 5.99 & 3.35 \\
\hline \multirow{3}{*}{ K } & Phenolic foam & 20.63 & 26.57 \\
\hline & Expanded vermiculite & 18.38 & 22.75 \\
\hline & Coconut shell fiber & 20.63 & 16.75 \\
\hline
\end{tabular}

study. In addition, unlike the aquaponic system, the hydroponic system led to high $\mathrm{N}$ contents in the leaf tissues, regardless of the substrate used. $\mathrm{N}$ content is a parameter widely evaluated in soilless cultivation systems because, when inadequately managed, these systems cause high accumulation of nutrients in the leaves, particularly in the form of nitrates (Aprígio et al., 2012).

In general, for the substrates evaluated, under the conditions of the present study, the coconut shell fiber was more adequate for lettuce production in both systems (aquaponic and hydroponic).

Considering the numerous advantages of the aquaponic cultivation, e.g. reduction in water consumption, no need for pesticide application, production of two income sources (plant cultivation and fish farming), production of biogas and biofertilizer, since the solid wastes from fish farming can be used in a biodigester etc. (Martins et al., 2010; Hoque et al., 2012; Ihejirika et al., 2012), it is necessary to seek instruments that make its application viable under Brazilian conditions.

Optimization of production systems is one of the main criteria to obtain economic viability in the aquaponic system (Tokunaga et al., 2015). Therefore, for future research on aquaponics, this study suggests small nutritional supplementations to plants using synthetic fertilizers. We believe that, by doing this, it is possible to increase the scale of plant production, maintaining the same structure of intensive fish farming. Consequently, both production systems (plant production and fish farming) would be operating in an optimized way.

\section{Conclusions}

1. The substrate composed of coconut shell fiber was more adequate for lettuce cultivation, since it led to higher yields in both aquaponic $\left(2.88 \mathrm{~kg} \mathrm{~m}^{-2}\right)$ and hydroponic $\left(2.58 \mathrm{~kg} \mathrm{~m}^{-2}\right)$ systems.

2. Using phenolic foam as cultivation substrate led to lower mean yield, in both production systems analyzed.

\section{Literature Cited}

Almeida, T. B. F.; Prado, R. D. M.; Correia, M. A. R.; Puga, A. P.; Barbosa, J. C. Avaliação nutricional da alface cultivada em soluções nutritivas suprimidas de macronutrientes. Biotemas, v.24, p.27-36, 2011.

Aprígio, A.; Rezende, R.; Freitas, P. S. L. de; Costa, A. R. da; Souza, R. S. de. Teor de nitrato em alface hidropônica em função de vazões e períodos de pós-colheita. Revista Brasileira de Engenharia Agrícola e Ambiental, v.16, p.946-951, 2012. https:// doi.org/10.1590/S1415-43662012000900004

Bezerra Neto, E.; Barreto, L. As técnicas de hidroponia. Anais da Academia Pernambucana de Ciência Agronômica, v.8, p.107137, 2012.

Coêlho, A. A. da C.; Bezerra, J. H. C.; Silva, J. W. A. da; Moreira, R. T.; Albuquerque, L. F. G. de; Farias, W. R. L. Desempenho zootécnico de alevinos de tilápia do Nilo cultivados em um sistema de recirculação de água com a microalga Spirulina platensis. Revista Brasileira de Saúde e Produção Animal, v.15, p.149-159, 2014. https://doi.org/10.1590/S1519-99402014000100024 
Ferreira, D. F. Sisvar: A computer statistical analysis system. Ciência e Agrotecnologia, v.35, p.1039-1042, 2011. https://doi.org/10.1590/ S1413-70542011000600001

Geisenhoff, L. O.; Jordan, R. A.; Santos, R. C.; Oliveira, F. C. de; Gomes, E. P. Effect of different substrates in aquaponic lettuce production associated with intensive tilapia farming with water recirculation systems. Engenharia Agrícola, v.36, p.291-299, 2016. https://doi. org/10.1590/1809-4430-Eng.Agric.v36n2p291-299/2016

Goddek, S.; Espinal, C. A.; Delaide, B.; Jijakli, M. H.; Schmautz, Z.; Wuertz, V.; Keesman, K. J. Navigating towards decoupled aquaponic systems: A system dynamics design approach. Water, v.8, p.303-332, 2016. https://doi.org/10.3390/w8070303

Hoque, S.; Webb, J. B.; Danylchuk, A. J. Building integrated aquaculture. Ashrae Journal, v.54, p.16-24, 2012.

Hundley, G. M. C.; Navarro, R. D.; Figueiredo, C. M. G.; Navarro, F. K. S. P.; Pereira, M. M.; Ribeiro Filho, O. P.; Seixas Filho, J. T. Aproveitamento do efluente da produção de tilápia do Nilo para o crescimento de manjericão (Origanum basilicum) e manjerona (Origanum majorana) em sistemas de aquaponia. Revista Brasileira de Agropecuária Sustentável, v.3, p.51-55, 2013.

Ihejirika, C.; Onwudike, S.; Nwaogu, L.; Emereibeole, E. I.; Ebe, T. E.; Ejiogu, C. C. Assessment of aquaculture sediment for agricultural fertilizer supplement and soil conditioner in Owerri Urban, Nigeria. Journal of Research in Agriculture, v.1, p.34-38, 2012.

Jordan, R. A.; Geisenhoff, L. O.; Oliveira, F. C.; Santos, R. C.; Martins, E. A. S. Yield of lettuce grown in aquaponic system using different substrates. Revista Brasileira de Engenharia Agrícola e Ambiental, v.22, p.27-31, 2018. https://doi.org/10.1590/1807-1929/agriambi. v22n1p27-31

Kano, C.; Cardoso, A. I. I.; Villas-Bôas, R. L. Acúmulo de nutrientes e resposta da alface à adubação fosfatada. Biotemas, v.25, p.39-47, 2012. https://doi.org/10.5007/2175-7925.2012v25n3p39

Love, D. C.; Fry, J. P.; Li, X.; Hill, E.; Genello, L.; Semmens, K.; Thompson, R. E. Commercial aquaponics production and profitability: Findings from an international survey. Aquaculture, v.435, p.67-74, 2015. https://doi.org/10.1016/j. aquaculture.2014.09.023
Martins, C. I. M.; Eding, E. H.; Verdegem, M. C. J.; Heinsbroek, L. T. N.; Schneider, O.; Blancheton, J. P.; D’Orbcastel, E. R.; Verreth, J. A. J. New developments in recirculating aquaculture systems in Europe: A perspective on environmental sustainability. Aquacultural Engineering, v.43, p.83-93, 2010. https://doi. org/10.1016/j.aquaeng.2010.09.002

Peixoto Filho, J. U.; Freire, M. B. G. dos S.; Freire, F. J.; Miranda, M. F. A.; Pessoa, L. G. M.; Kamimura, K. M. Produtividade de alface com doses de esterco de frango, bovino e ovino em cultivos sucessivos. Revista Brasileira de Engenharia Agrícola e Ambiental, v.17, p.419-424, 2013. https://doi.org/10.1590/S141543662013000400010

Pôrto, M. L. A.; Alves, J. do C.; Souza, A. P. de; Araújo, R. da C.; Arruda, J. A. de; Tompson Júnior, U. Doses de nitrogênio no acúmulo de nitrato e na produção da alface em hidroponia. Horticultura Brasileira, v.30, p.359-543, 2012. https://doi. org/10.1590/S0102-05362012000300030

Raij, B. van; Cantarella, H.; Quaggio, J. A.; Furlani, A. M. C. Recomendações de adubação e calagem para o estado de São Paulo. 2.ed. Campinas: IAC, 1996. 279p.

Roosta, H. R.; Afsharipoor, S. Effects of different cultivation media on vegetative growth, ecophysiological traits and nutrients concentration in strawberry under hydroponic and aquaponic cultivation systems. Advances in Environmental Biology, v.6, p.543-555, 2012.

Salam, M. A.; Jahan, N.; Hashem, S.; Rana, K. M. S. Feasibility of tomato production in aquaponic system using different substrates. Progressive Agriculture, v.25, p.54-62, 2014. https:// doi.org/10.3329/pa.v25i0.24075

Tokunaga, K.; Tamaru, C.; Ako, H.; Leung, P. Economics of smallscale commercial aquaponics in Hawai'i. Journal of the World Aquaculture Society, v.46, p.20-32, 2015. https://doi.org/10.1111/ jwas. 12173

Villela Júnior, L. V.; Araújo, J. A.; Factor, T. Análise do resfriamento da solução nutritiva para cultivo hidropônico do morangueiro. Engenharia Agricola, v.24, p.338-346, 2004. https://doi. org/10.1590/S0100-69162004000200012 